\title{
Address System of Gayonese Lut and Deret in Bener Meriah
}

\author{
Cut Kemala Sari ${ }^{1, *}$ Zainuddin $^{2}$ Anni Holila Pulungan ${ }^{3}$
}

\author{
${ }^{1}$ English Applied Linguistics, Universitas Negeri Medan, Medan, Indonesia \\ ${ }^{2}$ English Applied Linguistics, Universitas Negeri Medan, Medan, Indonesia \\ ${ }^{3}$ English Applied Linguistics, Universitas Negeri Medan, Medan, Indonesia \\ *Corresponding author. Email: cutkemalasari26@gmail.com
}

\begin{abstract}
This study deals with Address System in one ethnic namely Gayonese Lut and Deret in Bener Meriah.The objective of this study is to investigate the types of address system Gayonese Lut and Deret in Bener Meriah. This research applied qualitative descriptive method. The techniques for collecting data were through giving the questionnaire sheets to the twelve subjects and record the conversation of interview with subjects and also the informants by taking the video directly. The results of this study found that Gayonese Lut has six types address system, Title Alone is the most dominant type found (27.22\%), there is a new finding namely Title plus First Name. Gayonese Deret only has four types of address system, First name is the most dominant type found (41.67\%). In Gayonese Deret, Last Name and Title Plus Last Name are not used as address system because all types of name only use first name in Gayonese Deret. Title plus First name is also as new finding of address system in Gayonese Deret.
\end{abstract}

Keywords: Address System, Gayonese, Lut, Deret.

\section{INTRODUCTION}

Through communication, people can interact and build a relationship each other. Usually, people use the different way in conveying the language, it base on the level of closeness between the speaker and the receiver. Communication is effective when the addresses or receiver understand the role, meaning, and purpose of the language that is given by the speaker, in another word there is no misunderstanding between addresser and addresses. Every society has their own way in communicating and each language shows the social character of the speaker or address. It shows how close their relationship between one and others.

Crystal (2008) stated that address term is a term used to refer to someone in a direct linguistic interaction, while Kridalaksana (2008) explained address term is a morpheme, word or phrase to refer to someone in social relations implying situational contexts based on the relation between speaker and the addressee. According to Wardhaugh (2006) address system is the way of people to call or address other people. He argues there are various ways on how people address others such as by using title, first name, last name, etc. Parkinson
(1985) argues that address term is words used in communication that refer to the addressee of that speech event, can be very important carriers of social information. Address term is a word or phrase for addressing someone.

The choice of certain types of address term is reflected in the condition of the speaker. For example the use of the title such as "Doctor" or "Professor", to address other people indicates the least intimate between the speaker and the addressee. It can be concluded that the speaker and the addressee do not know each other and do not have close relationship. Wardhaugh (2006) states there are six types of address systems namely first name (FN), last name (LN), title plus last name (TLN), nick name or pet name (N/P), kinship terms (K), and title only (T). People who do not belong to the same society will find it difficult to understand the basic rules of how to use the addressing terms of other language. Every culture has their own patterning of address system in communication, the first reason is to mark or to identity someone and to create the politeness. In this research, the researcher will conduct a research of address system in Gayo Language. Hasan (1980) 
divided Gayonese into four based on the inhabitation namely Gayo Lut who lives around lake Laut tawar; Gayo Deret or Gayo Lues who lives around Gayo Lues, Gayo Alas who lives around southeast Aceh, and Gayo Serbejadi who lives around Serbejadi-Sembuang Lukup area. The researcher focused the two types of address system namely Gayonese Lut and Deret.

\section{LITERATURE REVIEW}

\subsection{Sociolinguistics}

The word sociolinguistics derives from a word socio and linguistics. The basic scope of sociolinguistics covers language and society since it is a combination of sociology and linguistics. This term is supported by Bussmann (2006) states that sociolinguistics is scientific discipline developed from the cooperation of linguistics and sociology that investigates the social meaning of the language system and of language use, and the common set of conditions of linguistic and social structure. Bernard Spolsky (1998) states sociolinguistics gives an informative overview of the various key concepts involved in this prominent sub-field of linguistics. It is the field that studies the relation between language and society, between the uses of language and the social structures in which the users of language live.

\subsection{The Description of Address System}

Brown Richards and Schmidt (2002), addressing terms is the word or words used to address somebody in speech or writing. The way in which people address one another usually depends on their age, sex, social group, and personal relationship. The different way people address the other is do the different situation and context in which they are involved. Wardhaugh (2006) argues that Address system is the way of someone to call or to address someone else that functions to maintain the relationship and it is a pattern in communication. Chaika (1982), addressing is different from greeting. First, addressing is used by people when they want to show their power or solidarity to other people, while greeting depends on the mood of the speaker. Second, people use the address terms to strengthen intimacy and power between people. On the other hand, people greet others only when they want to set the stage.

Wardhaugh (2006) also states the use of the address terms are influenced by social status, gender, age, family relationship, occupational hierarchy, race, and degree of intimacy. He argues that there are six types of address system namely are Title Alone (T), First Name (FN), Last Name (LN), Title plus Last Name (TLN), Nick Name or Pet Name (N/P), and Kinship (K). The aim of addressing terms shows the social relationship between an addresser and an addressee in society.
Generally, someone has more than one name and it uses in different situation. For example, a father is called daddy in his house by his family, but in another places someone calls him as sir or Mr.

\subsection{Gayo Lut}

Gayo Lut is a sub-group of the Gayo people whose area of origin is in the Central Aceh Regency area in the province of the Special Region of Aceh. This group inhabits nine sub-districts, namely Takengon City, Bebesen Bukit, Tunang Gajah, Bandar, Silih Nara, Pegasing, Bintang and Linge Districts. Gayo Lut community, like other societies, has a cultural system as a reference in its survival as a social unit. Melalatoa (1995) argues that the cultural system of Gayo community that has been manifested for a long time is derived from what they call "Edet and Hukum".

\subsection{Gayo Deret}

Hasnah (1996) argues that Gayo Deret is the territory of Reje Patiambang. The regency was created in 2002 under Statute UU 4/2002 from the northern part of Aceh Tenggara (Southeast Aceh Regency) and the capital is Blangkejeren. $90 \%$ of the inhabitants make their living from farming. Gayo Deret or Gayo Lues is no stranger to all residents in the land of Aceh and Gayo. Gayo comes from an ancient Acehnese language was adopted from Sanskrit which is means Mountain and Lues means Broad in the local language. So it can be concluded that Gayo Lues means broad mountains or broad mountains located in a row of hills.

\section{RESEARCH METHOD}

This research used descriptive qualitative research. Miles, Huberman, and Saldana (2014) state that qualitative research is conducted through intense and/or prolonged contact with participants in a naturalistic setting to investigate the everyday and/or exceptional lives of individuals, groups, societies, and organizations.

The data of this research were the words and phrases consist of address system of Gayonese Lut and Gayonese Deret. The words and phrases of address system obtained from questionnaire and interview directly and it had been transcribed in the written form. The sources of data were the 20 subjects of native speakers of Gayonese where 10 native speakers are Gayonese Lut and 10 more were Gayonese Deret.

\section{RESULT AND DISCUSSION}

Based on theory of Wardhaugh (2006), there are six types of address system used in daily communication, they are; Title Alone (T), First Name (FN), Last Name (LN), Title plus Last Name (TLN), Nick Name or Pet 
Name (N/P), and Kinship (K). There are six types of address system found in Gayonese Lut and there is a new finding namely Title plus First Name while in Gayonese Deret in Gayonese Deret, there are four types found and also new finding namely Title plus First Name. Last Name and Title plus Last Name are not used as address system in Gayonese Deret. It can be seen in the table 4.1 below.

Table 4.1 Types of Address System

\begin{tabular}{|c|c|c|c|}
\hline $\begin{array}{l}\mathrm{N} \\
\mathbf{0}\end{array}$ & $\begin{array}{c}\text { Types of Address } \\
\text { System }\end{array}$ & $\begin{array}{c}\text { Gayones } \\
\text { e } \\
\text { Lut }\end{array}$ & $\begin{array}{c}\text { Gayones } \\
\text { e Deret }\end{array}$ \\
\hline & & \multicolumn{2}{|c|}{ Percentages (\%) } \\
\hline 1 & Title Alone $(\mathrm{T})$ & 27.22 & 26.11 \\
\hline 2 & First Name (FN) & 26.11 & 41.67 \\
\hline 3 & Last Name (LN) & 17.22 & 0 \\
\hline 4 & $\begin{array}{l}\text { Title plus First } \\
\text { Name (New Finding) }\end{array}$ & 13.33 & 18.89 \\
\hline 5 & $\begin{array}{l}\text { Special Nick Name/ } \\
\text { Pet Name (N/P) }\end{array}$ & 7.78 & 7.77 \\
\hline 6 & Kinship (K) & $5 . .56$ & 5.56 \\
\hline 7 & $\begin{array}{l}\text { Title plus Last Name } \\
(\text { TLN) }\end{array}$ & 2.78 & 0 \\
\hline & Total & 100 & 100 \\
\hline
\end{tabular}

Table 4.1 shows the types of address system used in Gayonese Lut and Deret. There are found six types of address system in Gayo Lut and new finding namely Title plus First Name, the most dominant type of address system used is Title Alone (27.22\%) and the lowest frequency is Title plus Last Name (2.78\%). In Gayo Deret, there are found four types of address system and also new finding (Title plus First Name), the most dominant type used is First Name (41.67\%) and the lowest is Kinship (5.56\%).

Last Name (LN) and Title plus Last Name (TLN) are not used for address system in Gayo Deret because for all name should use the first name, the philosophy is because first name as the beginning of name, what appears first is what is used. The same case in using address system, what is the first should be used in Gayo Deret such as to call son in law, the address system used is Aman plus his first child's name. For example his first child's name is Satria so other older family member call him Aman Satria, it cannot be used the second or third child's name but should be used the first child's name.

\section{CONCLUSION}

There are ix types address system in Gayonese Lut, they are Title Only (T), Title plus last name (TLN),
Special Nick Name/Pet Name (N/P), First Name (FN), Last Name (LN), Kinship Terms (K), and another finding Title plus First Name. In Gayonese Deret, there were four types address system namely Title Only (T), Special Nick Name/Pet Name (N/P), First Name (FN), Kinship Terms (K), and another finding Title plus First Name. Last Name and Title plus Last name was not found in Gayonese Deret because the society only use first name to address someone else and it has philosophical value. In another word, not all Wardhaugh's theory work in this research.

\section{REFERENCES}

[1] Bussman, H. (2006). Routledge Dictionary of Language and Linguistics. New York: Routledge.

[2] Chaika, E. (1982). Language: The Social Mirror. USA: Newburry House Pybliosher.

[3] Crystal, D. (1969). Prosodic Systems and Intonation in English. Cambridge: Cambridge University Press.

[4] Hassan, A. (1980). Kesenian Gayo dan Perkembangannya. Jakarta: Balai Pustaka.

[5] Melalatoa, Harimurti, K., Ahmad, B., Asiah, A.M., and Abu, D.B. (1985). Kamus

[6] Bahasa Gayo-Indonesia. Jakarta: Pusat Pembinaan dan Pengembangan Bahasa.

[7] Miles, M. B., A.M.Huberman and J. Saldana. (2014). Qualitative Data Analysis. Newbury Park: Sage Publications.

[8] Parkinson, D. (1985). Constructing The Social Context of Communication. Berlin: Mouton De Gruyter.

[9] Wardaugh, R. (2006). An Introduction to

Sociolinguistics. Oxford: Blackwell Publishing Ltd. 